\title{
Corporate Governance Disclosure: The Evidence from Nigeria
}

\author{
Abubakar M. Dembo* \\ University of Bedfordshire, United Kingdom
}

\begin{abstract}
This study centres on the investigation of the level of compliance with the Nigerian Corporate Governance Code's recommendations by the six selected oil companies from 2004 to 2012. Two stages of compliance level with the Corporate Governance Disclosure Index (CGDI) were developed from 43 specific corporate governance issues based on the Nigerian Code's provisions and analysed. Firstly, the study demonstrates the degree of compliance with the CGDI for the selected companies over the survey period (2004-2012). This allows the testing of the continuous progress of the level of conformity with the Nigerian Code's provisions. Second, it measures the level of compliance with the CGDI that existed over the 2004-2009 and 2010-2012 periods respectively. The motive is to find out whether the level of compliance with corporate governance has increased over the two periods since the creation of the Nigerian Code in late 2003. The findings indicate a remarkable improvement with the compliance with the Nigerian Code over the periods by the selected companies.
\end{abstract}

Keywords: Corporate Governance, Compliance, Financial, Nonfinancial, Disclosure, Oil Companies

JEL Classification: G30, G38

Paper Type: Research

\section{INTRODUCTION}

Corporate governance has continued to receive a high level of attention globally since the early 1990s from the policy-makers, academia and the public. This increasing attention, have made countries to adopt new practices. One such is the introduction of codes of good governance to complement the statutory laws (Aguilera and Cuervo-Cazurra, 2004).

* Corresponding author: E-mail: abubakar.dembo@beds.ac.uk, Phone: +44774768685 
A number of lessons have been learned from the series of corporate collapses that includes WorldCom, Enron, Parmalat, Lehman Brothers, Northern Rock, and RBS to mention a few that occurred in different parts of the world in the last decade. In this study, six oil companies listed on the Nigerian Stock Exchange (NSE) has been selected, and the following issues have been framed for empirical study; composition of Board of directors; the roles and responsibilities of the board; board appointment process; evaluation process; composition of board committees; description of the roles and responsibilities of the board committees; the number of meetings of the board and the committees held during the year and the attendance of individual directors at those meetings; disclosure of the code of business conduct and ethics, if any, for directors and employees.

In the light of above, this study examined the level of compliance with the corporate governance code in Nigeria. The corporate governance practices adopted by the six oil companies as disclosed in their yearly reports for the fiscal years 2004 to 2012 were analysed.

\section{LITERATURE REVIEW}

\subsection{Guidance on Good practices}

The United Nation (UN) member States since the collapses that took place in USA, UK, Asia has undertaken various actions to strengthen their regulatory frameworks in this area in order to restore investor confidence and enhance corporate transparency and accountability. The topic of corporate governance has been on the UN's agenda since the tenth United Nation Conference on Trade and Development (UNCTAD) quadrennial conference held in Bangkok in February 2000, where the member States requested UNCTAD to promote improved practices in this area. In response to these yearnings, the UNCTAD set up the Intergovernmental Working Group of Experts on International Standards of Accounting and Reporting (ISAR) that conducted a number of consultations and deliberations on corporate governance disclosure during their annual sessions with a view to assisting developing countries and countries with economies in transition in identifying and implementing good corporate governance practices. All this was undertaken as part of the larger goal of achieving better corporate transparency and accountability in order to facilitate investment flows and mobilise financial resources for economic development.

The ISAR at its 21st session in 2004, agreed to consider further developments in the area of disclosures and to update its earlier work as needed. Accordingly, the updating work was conducted and reviewed at the 22nd session of the ISAR in 2005, where it was decided to prepare the guidance for publication and disseminate it as widely as possible. The main purpose of the guidance is to assist the preparers of enterprise reporting in producing disclosures on corporate governance, which will address the major concerns of investors and other stakeholders. This work would be relevant to enterprises eager to attract investment, regardless of their legal form or size. This guidance would also be useful for promoting awareness in countries and companies that are not sufficiently adhering to international best practices and are consequently failing to satisfy investors' expectations regarding corporate governance disclosures.

The published guidance draws upon recommendations for disclosure relevant to corporate governance contained in such widely recognized documents as the revised OECD Principles of Corporate Governance (OECD Principles), the International Corporate Governance Network (ICGN) Corporate Governance Principles, past ISAR conclusions on this matter, the Commonwealth Association for Corporate Governance 
Guidelines (CACG Guidelines), the pronouncements of the European Association of Securities Dealers (EASD), the EU Transparency Directive, the King II Report on Corporate Governance for South Africa, the Report of the Cadbury Committee on the Financial Aspects of Corporate Governance (Cadbury Report), the Combined Code of the UK, the United States Sarbanes-Oxley Act, and many others.

The document titled "UNCTAD publication Guidance on Good Practices in Corporate Governance Disclosure" contained 52 disclosure items as a benchmark. The 52 disclosure items cover the following five broad categories:

(a) Ownership structure and exercise of control rights;

(b) Financial transparency and information disclosure;

(c) Auditing;

(d) Corporate responsibility and compliance; and

(e) Board and management structure and process.

This study has used the SEC (2003) and SEC (2011) Code's recommendations in conjunction with the benchmark of good practices in corporate governance disclosure developed by the Intergovernmental Working Group of Experts on International Standards of Accounting and Reporting (ISAR) respectively to decide the score of corporate governance in the selected oil companies to disclose their corporate governance practices.

Bhasin (2010) used a 'point-value-system' to analyse disclosures made by an Indian Company and concluded that the company has shown 'very good' performance. Similarly, Dembo and Rasaratnam (2014) in their study that explores the standard and quality of CG practices disclosed by Oando PLC, over the period 2010-2012, using the Nigerian 2011 Code as a benchmark, indicated the company had complied with the Nigerian corporate governance code, in reference to transparency and internal control with "Excellent" performance.

Furthermore, Panchasara and Bharadia (2013) examines the corporate governance (CG) disclosure practices of selected Indian Banks by using the financial and non-financial parameters as explained in the 'Guidance on Good Practices in Corporate Governance Disclosure' issue by the ISAR (International Standards of Accounting and Reporting). The study analysed the corporate governance disclosure practices followed by Indian Banks in their annual reports for the period of 2007-08 to 2011-12. Based on the parameters, Corporate Governance Disclosure Index (CGDI) is formatted in such a way that it helps in evaluating the corporate governance disclosure practices of each bank.

As per the guidelines of UNCTAD, corporate governance disclosure can be divided into two parts:

- Financial Disclosures

- Nonfinancial Disclosures

The financial disclosures deal with the financial documentation and disclosure practices of the firms.

Table 1. Financial Disclosures

\begin{tabular}{cl}
\hline S/N & Disclosure Item \\
\hline 1 & Statement of Directors Responsibilities \\
2 & Report of the Independent Auditors \\
3 & Balance Sheet \\
4 & Profit and Loss Account \\
5 & Statement of Cash Flows \\
6 & Consolidated Financial Statement \\
7 & Notes to the Financial Statements \\
\hline
\end{tabular}




\begin{tabular}{cl}
\hline S/N & Disclosure Item \\
\hline 8 & Significant Accounting Policies \\
9 & Related Party Transaction \\
10 & Statement of Value Added \\
11 & Five-Year Financial Summary \\
\hline
\end{tabular}

Nonfinancial disclosures deal with the other than financial documentation and disclosures by the firm.

Table 2. Nonfinancial Disclosures as per SEC Codes

\begin{tabular}{|c|c|}
\hline & Nonfinancial Disclosures \\
\hline Disclos & tems \\
\hline Compa & bjectives \\
\hline 1 & Vision \& Mission Statement \\
\hline 2 & Chairman's Report \\
\hline 3 & Director'/Chief Executive's Report \\
\hline Owners & \& Shareholders' Right \\
\hline 4 & Shareholding Structure \\
\hline 5 & Shareholders' Right \\
\hline Board & Management structure and process \\
\hline 6 & Composition of board of directors (executives and non-executives) \\
\hline 7 & Size of the Board (Minimum of 5 , Maximum of 15 ) \\
\hline 8 & Chairman \& CEO Duality \\
\hline 9 & Role \& Functions of the Board \\
\hline 10 & Qualifications and biographical data on board members \\
\hline 11 & Number of Board Meetings (At least once every quarter) \\
\hline 12 & Attendance of Board Meetings (2/3 of meetings for renewal) \\
\hline 13 & Determination and composition of directors' remuneration \\
\hline 14 & Existence of procedure(s) for addressing conflicts of interest among board members \\
\hline 15 & Audit Committee (At least 3 times in a year) \\
\hline 16 & Governance/Remuneration Committee \\
\hline 17 & Risk Management Committee \\
\hline 18 & Other Committees \\
\hline 19 & Function of Committees \\
\hline 20 & Composition of Committees \\
\hline 21 & Organizational Code of Ethics \\
\hline 22 & Professional development and training activities \\
\hline 23 & Performance evaluation process \\
\hline Issues & nployee Relation, Social/Environmental \\
\hline 24 & Employee Relation/ Industrial Relation \\
\hline 25 & Policy on "whistleblower" protection for all employees \\
\hline 26 & Corporate Social/Environmental Responsibility \\
\hline Auditin & \\
\hline 27 & Internal Control System \\
\hline 28 & Auditor Appointment \& Rotation \\
\hline Annual & eral Meeting \\
\hline 29 & Notice \& Agenda of the AGM \\
\hline Means & sclosure \\
\hline 30 & Separate CG Statement/ Section \\
\hline 31 & Investors' portal on the website \\
\hline Compli & with CG \\
\hline 32 & Recognition/Award for CG \\
\hline
\end{tabular}

\section{RESEARCH METHODOLOGY}

This study has selected six oil companies listed on the Nigerian Stock Exchange (NSE). The companies are the top in the sector and among the top 30 companies on the exchange. The companies were chosen because they are the most capitalised, being in existence and operation for the duration of the study. The Corporate Annual Reports 
(CAR) for the period 2004-2012 for these companies was obtained from the Nigerian Stock Exchange (NSE) and the respective company's websites. The motive behind the selection of the period 2004-2012 was because the corporate governance guidelines were introduced in Nigeria in the second quarter of 2003.

By 2008 , a review committee was inaugurated by SEC to look at the weaknesses of the 2003 code and recommend ways of effecting compliance. A draft report was submitted by the committee in 2009 of which most of the companies tried to comply with the draft report in 2010 before it was enforced in 2011. Therefore, the period 2004-2009 was necessary to observe the effectiveness of the SEC code of 2003 on performance. The period 2010-2012 was when the revised code was put into use by the companies. Content analysis of the CARs and the exploring of the corporate websites of all the 6 companies selected were done to study the degree of compliance with the Nigerian code of corporate governance to develop a Corporate Governance Disclosure Index (CGDI). The development of the CGDI followed the work of (Gompers et al., 2001; Garay \& González, 2008; Panchasara 2012), where a system of scoring corporate governance disclosures in CARs was established. The method is binary coding that consists of awarding a value of " 1 " if a specific Nigerian corporate governance provision is revealed in the CARs or " 0 " if else.

The financial disclosure section of the CGDI has 11 provisions, while the non-financial disclosure section has 32 provisions bringing the total provisions to 43 . Precisely, the scoring process involves going through each firm's CAR and awarding one point if a particular corporate governance provision is disclosed or zero if not (Panchasara, 2012), The total score of a company a specific year range from zero to forty-three points, zero points gives $0 \%$ indicating perfect non-compliance and 43 points expresses $100 \%$ indicating full compliance.

The list of the companies selected for the study is as in table 3 below:

Table 3. Selected Companies for the Research

\begin{tabular}{clcc}
\hline S/N & Company & $\begin{array}{c}\text { Wholly Owned by Nigerians } \\
\text { (GROUP I) }\end{array}$ & $\begin{array}{c}\text { Partly Owned by Nigerians } \\
\text { (GROUP II) }\end{array}$ \\
\hline 1 & Conoil Plc & $\mathrm{X}$ & \\
2 & Forte Oil Plc & $\mathrm{X}$ & $\mathrm{X}$ \\
3 & Mobil Oil Nigeria Plc & $\mathrm{X}$ & \\
4 & MRS Oil Nigeria Plc & $\mathrm{X}$ & $\mathrm{X}$ \\
5 & Oando Plc & & \\
6 & Total Nigeria Plc & & \\
\hline
\end{tabular}

The companies are divided into two groups: Wholly owned by Nigerians and partially owned by Nigerians. Table 3 shows the list of oil companies which are wholly owned by Nigerians, which contains a total of 4 companies. Out of the total sample size, the majority is from the wholly owned by Nigerians [66.67\%]. Also from Table 3, it shows the list of companies which are partly owned by Nigerians, which contains the total 2 companies. Out of the total sample size, partly owned by Nigerians oil companies are $33.33 \%$.

\section{ANALYSIS OF DISCLOSURES BY SAMPLE COMPANIES}

As mentioned earlier, the corporate governance index in this study is based on the financial and non-financial disclosures as per the guidelines for good governance practices issued by the UNCTAD as contained in the 2003 and 2011 SEC Codes. The analysis was conducted by reviewing the CARs and other company documents that are available publicly (Panchasara, 2012). The statistics in this study are mainly based on the data from the CARs. 


\subsection{Analysis of Financial Disclosure Index of Sample Companies}

With this reference in mind, this study has developed the financial disclosure index of each selected oil company given as in Table 2 for nine years from 2004-12. The financial disclosure index contains a total of 11 items, and each was allocated the score of 1 for each year and nine years. In this way, the maximum score of the financial index is 99 . For the purpose of company analysis of financial disclosure index, the researcher has divided the companies into two groups. The group I - Wholly Owned by Nigerians and Group II Partly Owned by Nigerians.

Thus, after analysing the financial disclosures of the two groups, Table 4 below is a summary of the selected company's compliance level for the periods 2004-2009 and 20102012 for easy comparison with the performance of the companies when looking at the relationship between sustainability practices and corporate performance. Also from the Table 4 is the summary for the period 2004-2009 to establish the compliance level for the actual period when the 2003 SEC Code was used. While the period 2004-2012 is the total degree of compliance of the 2003 and 2011 SEC Codes by the listed oil companies.

Table 4. Summary of Financial Disclosure Score of the Groups

\begin{tabular}{|c|c|c|c|c|c|c|c|}
\hline $\mathbf{S} / \mathbf{N}$ & Coy & $\begin{array}{l}2004- \\
2009 \\
\text { Scores }\end{array}$ & $\begin{array}{l}\text { \% } \\
\text { Compliance }\end{array}$ & $\begin{array}{l}2010- \\
2012 \\
\text { Scores }\end{array}$ & $\begin{array}{l}\text { \% } \\
\text { Compliance }\end{array}$ & $\begin{array}{l}\text { 2004- } \\
2012 \\
\text { Scores }\end{array}$ & $\begin{array}{l}\% \\
\text { Compliance }\end{array}$ \\
\hline \multicolumn{8}{|c|}{ Group / Companies } \\
\hline 1 & Conoil Plc & 60 & 90.91 & 30 & 90.91 & 90 & 90.91 \\
\hline 2 & Forte Oil Plc & 54 & 81.82 & 30 & 90.91 & 84 & 84.85 \\
\hline 3 & $\begin{array}{l}\text { MRS Oil Nig. } \\
\text { Plc }\end{array}$ & 60 & 90.91 & 30 & 90.91 & 90 & 90.91 \\
\hline 4 & Oando Plc & 66 & 100 & 33 & 100 & 99 & 100 \\
\hline TOT & & $240 / 264$ & 90.91 & $123 / 132$ & 93.18 & $363 / 396$ & 91.67 \\
\hline \multicolumn{8}{|c|}{ Group II Companies } \\
\hline 1 & $\begin{array}{l}\text { Mobil Oil Nig. } \\
\text { Plc }\end{array}$ & 60 & 100 & 30 & 100 & 90 & 100 \\
\hline 2 & Total Nig. Plc & 60 & 100 & 30 & 100 & 90 & 100 \\
\hline \multicolumn{2}{|c|}{ TOTAL } & $120 / 120$ & 100 & $60 / 60$ & 100 & $180 / 180$ & 100 \\
\hline
\end{tabular}

Table 4 shows that of the four wholly owned by Nigerians under Group $\boldsymbol{I}$, only one company had full compliance with the financial disclosures throughout, which is Oando Plc. The company with the least compliance is Forte Oil PLC with an overall score of 84 and $84.85 \%$ of compliance level for the period 2004-2012. For the periods 2004-2009 and 2010-2012, the company had a score of 54 out 60 and 30 out of 33 respectively with the level of compliance to be $81.82 \%$ and $84 \%$ respectively. The company is lacking on disclosure of consolidated financial statement. Whereas in part owned by Nigerians under Group II, all the two companies had full compliance with the Financial Disclosures. The result also indicated that among all the selected oil companies, Forte Oil PLC has the least overall compliance of $84.85 \%$. The GroupWise score shows the $91.67 \%$ compliance in Group I and 100\% compliance in Group II, respectively for the period 2004-2012.

Overall, it is worth mentioning that Oando Plc from Group I, Mobil Oil Nigeria Plc and Total Nigeria Plc from Group II scored 100\% throughout the study in the financial disclosures. While all the remaining three companies, namely Conoil Plc, Forte Oil Plc and MRS Oil Nigeria Plc scored $90.91 \%$ each in the period 2010-2012. The GroupWise score shows the $93.18 \%$ compliance in Group I and 100\% compliance in Group II, respectively 
for the period $2010-2012$. This shows an increase in compliance of $2.27 \%$ between the periods.

\subsection{Analysis of Nonfinancial Disclosures Index of the Sample Companies}

After analysing the financial disclosure index of selected oil companies, the researcher went ahead to analyse the non-financial disclosure index of the selected oil companies using the items identified as shown in Table 2.

Using the same methodology as in the financial disclosure, the total items are 32 with a maximum score of 288 . The analysis is presented group wise. From Table 5, the overall result for the study period 2004-2012 shows the highest level of compliance of $88.19 \%$ with the score of 254 out of 288 is from Oando Plc from Group I. The last score of 172 out of 288 comes from Mobil Oil Nigeria Plc from Group II with a $59.72 \%$ level of compliance. GroupWise compliance shows the Group I with $72.66 \%$ and Group II with $65.45 \%$ respectively. For the periods 2004-2006 and 2007-2009, Oando Plc tops the chart with $73.96 \%$ and $90.63 \%$ respectively compliance level. Mobil Oil Nigeria Plc scored $55.21 \%$ and $61.46 \%$ level of compliance respectively to be least compliant among the selected oil companies.

Also from the same Table 5, the result indicates that for the period 2004-2009, Oando PIc has scored 158 out of 192 from Group I with the level of compliance of $82.29 \%$ to top the list. Mobil Oil Nigeria Plc scores of 112 out of 192 which translate to $58.33 \%$ to be the least among the selected oil companies. GroupWise compliance level shows Group I with $68.23 \%$ and Group II with $62.24 \%$.

Furthermore, the situation is the same for the period 2010-2012 as shown in Table 5. Oando PIc Scored 96 out 96 to $100 \%$ compliance level to top the chart from Group $I$. The last remains Mobil Oil Nigeria Plc with a score of 60 out 96 that translates to $62.50 \%$ compliance. The GroupWise compliance level shows Group I with $81.51 \%$ and Group II with $71.88 \%$.

Table 5. Summary of Nonfinancial Disclosure Score of the Groups

\begin{tabular}{|c|c|c|c|c|c|c|c|}
\hline $\mathbf{S} / \mathbf{N}$ & Coy & $\begin{array}{l}2004- \\
2009 \\
\text { Scores }\end{array}$ & $\begin{array}{l}\% \\
\text { Compliance }\end{array}$ & $\begin{array}{l}2010- \\
2012 \\
\text { Scores }\end{array}$ & $\begin{array}{l}\% \\
\text { Compliance }\end{array}$ & $\begin{array}{l}2004- \\
2012 \\
\text { Scores }\end{array}$ & $\begin{array}{l}\% \\
\text { Compliance }\end{array}$ \\
\hline \multicolumn{8}{|c|}{ Group I Companies } \\
\hline 1 & Conoil Plc & 128 & 66.67 & 72 & 75.00 & 200 & 69.44 \\
\hline 2 & Forte Oil Plc & 120 & 62.50 & 72 & 75.00 & 192 & 60.42 \\
\hline 3 & $\begin{array}{l}\text { MRS Oil } \\
\text { Nig. Plc }\end{array}$ & 118 & 61.46 & 73 & 76.04 & 191 & 61.81 \\
\hline 4 & Oando Plc & 158 & 82.29 & 96 & 100.00 & 254 & 88.19 \\
\hline \multicolumn{2}{|c|}{ TOTAL } & $524 / 768$ & 68.23 & $313 / 384$ & 81.51 & $837 / 1152$ & 72.66 \\
\hline \multicolumn{8}{|c|}{ Group II Companies } \\
\hline 1 & $\begin{array}{l}\text { Mobil Oil } \\
\text { Nig. Plc }\end{array}$ & 112 & 58.33 & 60 & 62.50 & 172 & 59.72 \\
\hline 2 & $\begin{array}{l}\text { Total Nig. } \\
\text { Plc }\end{array}$ & 127 & 66.15 & 78 & 81.25 & 205 & 71.18 \\
\hline \multicolumn{2}{|c|}{ TOTAL } & $239 / 384$ & 62.24 & $138 / 192$ & 71.88 & $377 / 576$ & 65.45 \\
\hline
\end{tabular}

In order to arrive at a total score for each company and group, the financial and nonfinancial disclosures scores are combined. Table 6 presents the full score of the selected oil companies in the corporate governance disclosure index. The result from the table indicates that the overall level of compliance of Group I companies is $77.52 \%$ with the score of 1200 out of 1548 and for Group II companies the compliance level is $73.68 \%$ with the score of 557 out of 756 . Therefore, the wholly-owned oil companies (Group I) have complied with more criteria of corporate governance than the partly owned oil. Oando Plc 
within that period had a total score of 353 out 387 which translate to $91.21 \%$ compliance level. Mobil Oil Nigeria Plc that scored 262 out 378 to $69.31 \%$ compliance levels was the last of them all.

Table 6. Total score for Sample Companies for Corporate Governance Disclosure Index 2004-2012

\begin{tabular}{llllll}
\hline S/N & Company & $\begin{array}{l}\text { Financial } \\
\text { Disclosure } \\
\text { Score }\end{array}$ & $\begin{array}{l}\text { Nonfinancial } \\
\text { Disclosure } \\
\text { Score }\end{array}$ & Total Score & $\begin{array}{l}\text { Compliance } \\
\mathbf{( \% )}\end{array}$ \\
\hline $\begin{array}{l}\text { Group } \\
1\end{array}$ & (Wholly Owned by Nigerians) & & & \\
2 & Conoil Plc & $90 / 99$ & $200 / 288$ & $290 / 387$ & 74.94 \\
3 & Forte Oil Plc & $84 / 99$ & $192 / 288$ & $276 / 387$ & 71.32 \\
4 & MRS Oil Nigeria Plc & $90 / 99$ & $191 / 288$ & $281 / 387$ & 72.61 \\
\hline TOTAL & Oando Plc & $99 / 99$ & $254 / 288$ & $353 / 387$ & 91.21 \\
\hline Group II (Partly Owned by Nigerians) & $\mathbf{3 6 3 / 3 9 6}$ & $\mathbf{8 3 7 / 1 1 5 2}$ & $\mathbf{1 2 0 0 / 1 5 4 8}$ & $\mathbf{7 7 . 5 2}$ \\
1 & Mobil Oil Nigeria Plc & $90 / 90$ & & & 69.31 \\
2 & Total Nigeria Plc & $90 / 90$ & $172 / 288$ & $262 / 378$ & 78.04 \\
\hline TOTAL & $\mathbf{1 8 0 / 1 8 0}$ & $\mathbf{3 7 7 / 5 7 6}$ & $\mathbf{5 5 7 / 7 5 6}$ & $\mathbf{7 3 . 6 8}$ \\
\hline
\end{tabular}

The compliance level of the selected oil companies within the 2004-2009 period. The period 2004-2009 was the total period when the 2003 SEC Code was in operation. From Table 7 the Group I companies scored a total of 764 out 1032 with the level of compliance of $74.03 \%$. The Group II companies scored a total of 359 out 504 which translate to $71.23 \%$ compliance level. Oando Oil Plc continued to dominate the first position among the companies with a total score of 224 out 258 with a compliance level of $86.82 \%$.

Table 7. Total score for Sample Companies for Corporate Governance Disclosure Index for 2004-2009

\begin{tabular}{|c|c|c|c|c|c|}
\hline $\mathbf{S} / \mathbf{N}$ & Company & $\begin{array}{l}\text { Financial } \\
\text { Disclosure } \\
\text { Score }\end{array}$ & $\begin{array}{l}\text { Nonfinancial } \\
\text { Disclosure } \\
\text { Score }\end{array}$ & Total Score & $\begin{array}{l}\text { Compliance } \\
\text { (\%) }\end{array}$ \\
\hline \multicolumn{6}{|c|}{ Group I (Wholly Owned by Nigerians) } \\
\hline 1 & Conoil Plc & $60 / 66$ & $128 / 192$ & $188 / 258$ & 72.87 \\
\hline 2 & Forte Oil Plc & $54 / 66$ & $120 / 192$ & $174 / 258$ & 67.44 \\
\hline 3 & MRS Oil Nigeria Plc & $60 / 66$ & $118 / 192$ & $178 / 258$ & 68.99 \\
\hline 4 & Oando Plc & $66 / 66$ & $158 / 192$ & $224 / 258$ & 86.82 \\
\hline TOT/ & & $240 / 264$ & $524 / 768$ & $764 / 1032$ & 74.03 \\
\hline \multicolumn{6}{|c|}{ Group // (Partly Owned by Nigerians) } \\
\hline 1 & Mobil Oil Nigeria Plc & $60 / 60$ & $112 / 192$ & $172 / 252$ & 68.25 \\
\hline 2 & Total Nigeria Plc & $60 / 60$ & $127 / 192$ & $187 / 252$ & 74.21 \\
\hline \multicolumn{2}{|c|}{ TOTAL } & $120 / 120$ & $239 / 384$ & $359 / 504$ & 71.23 \\
\hline
\end{tabular}

The period 2010-2012 shows the same trend as shown in Table 8.

Table 8. Total score for Sample Companies for Corporate Governance Disclosure Index 2010-2012

\begin{tabular}{|c|c|c|c|c|c|}
\hline $\mathbf{S} / \mathbf{N}$ & Company & $\begin{array}{l}\text { Financial } \\
\text { Disclosure } \\
\text { Score }\end{array}$ & $\begin{array}{l}\text { Nonfinancial } \\
\text { Disclosure } \\
\text { Score }\end{array}$ & Total Score & $\begin{array}{l}\text { Compliance } \\
\text { (\%) }\end{array}$ \\
\hline \multicolumn{6}{|c|}{ Group I (Wholly Owned by Nigerians) } \\
\hline 1 & Conoil Plc & $30 / 33$ & $72 / 96$ & $102 / 129$ & 79.07 \\
\hline 2 & Forte Oil Plc & $30 / 33$ & $72 / 96$ & $102 / 129$ & 79.07 \\
\hline 3 & MRS Oil Nigeria Plc & $30 / 33$ & $73 / 96$ & $103 / 129$ & 79.84 \\
\hline 4 & Oando Plc & $33 / 33$ & $96 / 96$ & $129 / 129$ & 100.00 \\
\hline TOT & & $123 / 132$ & $313 / 384$ & $436 / 516$ & 84.50 \\
\hline \multicolumn{6}{|c|}{ Group // (Partly Owned by Nigerians) } \\
\hline 1 & Mobil Oil Nigeria Plc & $30 / 30$ & $60 / 96$ & $90 / 126$ & 71.43 \\
\hline 2 & Total Nigeria Plc & $30 / 30$ & $78 / 96$ & $108 / 126$ & 84.71 \\
\hline \multicolumn{2}{|c|}{ TOTAL } & $60 / 60$ & $138 / 192$ & $198 / 252$ & 78.57 \\
\hline
\end{tabular}


The Group II companies still did not comply more with the CG with $78.57 \%$ level of compliance and score of 198 out of 252 as against that of Group I with a score of 436 out of 512 which translate to $84.50 \%$ level of compliance. This shows remarkable improvement over the periods by the companies in both Groups adopting more governance mechanisms. Still, Oando Plc leads the other companies with a score of 129 out 129 . This shows a $100 \%$ compliance with the CG disclosure in the annual reports and accounts for the period. Mobil Oil Nigeria Plc got 90 out 126 and $71.43 \%$ compliance level to be the last.

Table 9 shows the ranking of selected listed oil companies based on their total scores and level of compliance. Oando Plc is leading with the highest overall score of 353 and $91.21 \%$ level of compliance. This feat was achieved due to the periodic review of the company policies and practices over the years. This result shows Oando plc in the front position of employing best practices in Nigeria and could be looked upon as a 'role model' by other companies (Dembo \& Rasaratnam, 2014). The second position went to Total Nigeria Plc with a score of 295 and $78.04 \%$ level of compliance respectively. The company that took the 3rd place is Conoil PLC with a score of 290 and $74.94 \%$ compliance level. MRS Oil Nigeria Plc is in the fourth position with a score of 281 and $72.61 \%$ compliance level. The fifth rank goes to a Forte Oil PLC with a score of 276 and $71.32 \%$ level of compliance. The last and sixth position went to Mobil Oil Nigeria Plc with the score of 262 and $69.31 \%$ level of compliance.

Table 9. Ranking of Sample Companies for Corporate Governance Disclosure Index

\begin{tabular}{lllll}
\hline S/N & Company & Total Score & CGDI (\%) & Ranking \\
\hline 1. & Oando Plc & $353 / 387$ & 91.21 & $1^{\text {st }}$ \\
2. & Total Nigeria Plc & $295 / 378$ & 78.04 & $2^{\text {nd }}$ \\
3. & Conoil Plc & $290 / 387$ & 74.94 & $3^{\text {rd }}$ \\
4. & MRS Oil Nigeria Plc & $281 / 387$ & 72.61 & $4^{\text {th }}$ \\
5. & Forte Oil Plc & $276 / 387$ & 71.32 & $5^{\text {th }}$ \\
6. & Mobil Oil Nigeria Plc & $262 / 378$ & 69.31 & $6^{\text {th }}$ \\
\hline
\end{tabular}

\section{CONCLUSION}

In this study, the level of compliance with the corporate governance code in Nigeria was examined. The analysis finds relatively regular disclosure rate of corporate governance practice by the six selected companies, with an average of 26 fully disclosed items per enterprise. Twenty-five items were fully disclosed by the selected companies in the benchmark. The benchmark was characterised by low disclosure rates by the companies, with an average of 4 items not being disclosed by at least 5 out of the 6 companies selected. The fully disclosed items from each of the companies range from 26 to 30 items with Oando Plc leading the rest with 30 items fully disclosed.

The implication of this result suggests that some companies do not comply with all disclosure rules. The directors of companies have core responsibilities for setting strategic direction and overseeing their business affairs. It is also the duty of directors to make sure that companies under them comply with the disclosure requests by the regulatory authorities in Nigeria. In this respect, there is a serious need to create awareness among directors of the requirements and benefits to be derived from corporate governance disclosure and the need to reinforce disclosure in some areas.

Notwithstanding, it is worth noting that all companies witnessed improvement on their compliance between the two periods. This improvement may be attributed to the companies adopting more governance mechanisms between the periods. 


\section{REFERENCES}

Aguilera, R. V. \& Cuervo-Cazurra, A. (2004). Codes of Good Governance Worldwide: What is the Trigger? Organisation Studies, 25 (3), 415-443.

Bhasin, M. L. (2010). Corporate governance disclosure practices: The portrait of a developing country. International Journal of Business \& Management, 5(4), 150.

Dembo, A. M. \& Rasaratnam, S. (2014). Corporate Governance and Disclosure in Nigeria: An empirical study. Procedia-Social and Behavioral Sciences, 164, 161-171

Garay, U. \& González, M. (2008). Corporate Governance and Firm Value: The Case of Venezuela. Corporate Governance: An international review, 16 (3), 194-209.

Gompers, P. A., Ishii, J. L. \& Metrick, A. (2001). Corporate Governance and Equity Prices. National Bureau of Economic Research

Panchasara, Bhavik M., (2012). An empirical study on Corporate Governance in Indian Banking Sector (PhD. Thesis). Saurashtra University. Available from http://etheses.saurashtrauniversity.edu/id/964

Panchasara, B. M., \& Bharadia, M. H. S. (2013). Corporate governance disclosure practices and firm performance: evidence from Indian banks. Paradigm, 17(1-2), 88-98.

SEC (2003). The Code of Best Practices on Corporate Governance in Nigeria. Securities and Exchange Commission. Available from: sec.gov.ng/regulation/rules-codes/

SEC (2011). Code of Corporate Governance for Public Companies in Nigeria. Securities and Exchange Commission Available from sec.gov.ng/regulation/rules-codes/.

UNCTAD (2006). Guidance on Good Practices in Corporate Governance Disclosure. United Nations New York and Geneva. 